\title{
Swedish building policy and the manufacturers of single-family houses in the county of Dalarna. A collaboration for the future goal of the improvement of energy efficiency?
}

\author{
K. Perman \\ Solar Energy Research Centre (SERC), Dalarna University Falun Sweden \\ Tel: +46 23778727, Fax: +46 23778050,E-mail: kpm@du.se
}

\begin{abstract}
Sweden's goal is to reduce the use of energy per heated unit area in dwellings by 20 percent by 2020 , and by 50 percent by 2050. To fulfil these goals, Sweden's dependency on electricity and, in particular, the large use of electricity for heating must be taken into account. The aim of this article is to study the effects of the Swedish building regulations from 1 January 2010, with regard to improving energy efficiency. The article follows the energy policy revision through policy documents and interviews.
\end{abstract}

The political goal of reducing both the annual electrical energy and the maximum instant power for heating is, on the whole, fulfilled by more efficient heat pumps. The study also shows that, in spite of the stricter building regulations for electrically heated houses, the standard of insulation required for the building to fulfil the building regulations is dependent on the heating and ventilation systems installed in the house. These changes towards more stringent requirements are also counteracted by there not being the same requirements for the existing housing stock.

Keywords: Building policy, Energy efficiency, Manufacturers of single-family houses, Electrically heated houses.

\section{Nomenclature}

$A_{\text {temp }}$ the temperate area of the building

HRV exhaust and supply air ventilation with heat recovery.................................dimensionless

\section{Introduction}

The energy used in the built environment constitutes 40 percent of the total energy use in Sweden. Consequently, a more efficient use of energy within the built environment is one of the most important means of achieving sustainable community development and fulfilling the environmental and climate goals. [see also 1, 2].

Sweden's goal is to reduce the demand of energy per heated unit area in dwellings by 20 percent by 2020 and by 50 percent by 2050 [3]. To fulfil these goals, Sweden's dependency on electricity and, in particular, the large demand of electricity for heating must be taken into account. Sweden has the largest number of heat pumps of the member countries of the $\mathrm{E} U$. In 2008, almost 40 percent of single family houses in Sweden were heated completely or partially by heat pumps. [4, 5]. But the Swedish building regulations for electrically heated houses became stricter in 1 January 2010. The new building regulations concern the use of energy and power demand for new construction. The focus is partly on the supplied energy, i.e. purchased energy per $\mathrm{m}^{2}$ floor area, and partly on limiting the maximum power demand of electrically heated houses [6].

The aim of this article is to study the effects of the Swedish building regulations from 1 January 2010, with regard to improving energy efficiency. The research question is if the revised building regulations from 2010, regarding energy use and power demand for new 
buildings, have resulted in changed building construction and/or a choice of alternative heating systems.

\section{Theory and Methodology}

Evert Vedung considers that different outcomes follow an intervention by the government, for example taxation laws or state subsidies. By outcomes he means what happens when the specific intervention reaches those who Vedung calls final recipients- that is the individuals or groups which are the goal for the intervention - and the final recipients' action caused by the public intervention. Three different types of intervention can be distinguished: the immediate, the intermediate and the final result [7]. We use a model which focuses on goals and fulfilment of goals, called a side effect evaluation. The evaluation focuses on the goals, and if the interventions have resulted in the fulfilment of the set goals [7]. According to Evert Vedung, two questions have to be asked in order to study this. These are: do the results correspond to the agreed goals for the interventions? And, if so, does this depend on the intervention?

A qualitative method makes it possible to reach an understanding of people's behaviour in relation to the surrounding environment (Merriam 1994:46). The housing companies' accounts have been followed during a three year period from when the building regulations were being framed until they were in force. During the autumn 2009 and the spring 2010, 10 representatives from manufacturers of prefabricated, single-family houses ${ }^{1}$ were interviewed. They have their head offices and production in the county of Dalarna. The interviews focused on the house manufacturers' reasoning and how they acted during the period of transition from 1 February 2009 until 1 January 2010. After the building regulations came into force, follow-up interviews were carried out with the house manufacturers during the spring 2010 [see also 8]. Further analysed material is from group discussions from 2007, when researchers from Dalarna University and house manufacturers discussed heating systems which the companies could consider [see also 9].

\section{The building regulations after 2010: u-values, power and energy use.}

During the last 30 years there has been a change in households' choice of heating systems in Sweden. Owners of single-family houses have changed from using oil fired boilers to using more district heating, heat pumps and bio-fuels [10]. But the energy use per $\mathrm{m}^{2}$ heated area for new built premises and dwellings has, on the other hand, been constant from 1993 to 2005. An explanation which was given before the revision of the building regulations in 2006 was the lack of a requirement for improvement of energy efficiency [11].

The building regulations on energy management from 1 Jan 2010 concern permanent residences, and not vacation homes. The regulations imply, above all, a tightening up of the requirements for newbuilt, electrically heated houses with both an energy requirement and a power requirement. Even houses with waterborne electric heating and heat pumps are now classified as electrically heated if the installed power demand exceeds $10 \mathrm{~W} / \mathrm{m}^{2}$. For buildings

\footnotetext{
${ }^{1}$ The definition prefabricated, single-family housing companies includes three different groups: 1) companies which manufacture houses according to the client's requirements (customer adapted houses), 2) housing companies which produce standard houses, and houses according to the client's requirements, and also 3) housing companies which only manufacture standard houses (Fredling \& Sellin 2003).
} 
with other methods of heating there are no tightening up of the requirements ${ }^{2}$. There are even somewhat less stringent requirements in the north of Sweden because there are three different zones instead of the previous two climate zones (see table 1). An electric immersion heater or electric boiler is, however, almost always used as a temporary reserve in single-family houses, which is true, for example, for houses with solid fuel boilers. This means that, in principle, all houses would be classed as electrically heated, and only houses with district heating would be omitted. For this reason there is an exception in the building regulations which says that "the electric power in a solid fuel appliance, which is installed to be a temporary reserve, is not counted if the solid fuel appliance is constructed for permanent operation" [6]. During this period the importance of flexible heating systems is also emphasised and the opportunity for flexibility in new building encouraged [12].

The three climate zones are: the most northerly, climate zone I (the counties of Norrbotten, Västerbotten and Jämtland), with an alleviation in the requirements for houses which are not heated by electricity, compared with earlier requirements. Climate zone II consists of the central parts of Sweden, including the county of Dalarna, the region which is in focus in this article $^{3}$. Climate zone III comprises of the southern parts of the country.

The building regulations are based on the building's specific energy demand (see table 1) which is the energy use of the building divided by $\mathrm{A}_{\text {temp }}{ }^{4}$. The energy use of the building is the energy which is used for heating and domestic hot water, and also that part of the electricity supplied to the property which is related to the requirements of the building. This means all permanently installed equipment within, under, or on the outside of the building. Pumps, fans, cooling machinery and heating cables are included if they supply the building ${ }^{5}$. When fuel is used, the amount of fuel and its calorific value is used to calculate the energy demand. Energy from solar collectors and solar panels, and also free cooling which is taken directly from the ground is not included in the energy use of the building [6].

\footnotetext{
${ }^{2}$ According to The Swedish Board of Housing, Building and Planning's instructions all buildings shall be classified as electrically heated if the installed electric power demand for heating is greater than10 $\mathrm{W} / \mathrm{m}^{2}$.

${ }^{3}$ Climate zone II includes the counties of Västernorrland, Gävleborg, Dalarna and Värmland

${ }^{4} A_{\text {temp }}$ is the area of all the floors, including stairs and shafts, for the spaces which shall be heated to over $10^{\circ} \mathrm{C}$. A garage within the building may not be included in $A_{\text {temp, }}$, but its heating requirements shall be included in the energy use of the building (Boverket 2008,p.35).

${ }^{5}$ Fixed lighting in common areas shall be included but not lighting in gardens and on external footpaths. Neither shall electricity for other uses, for example as engine pre-heaters and car coupé heaters, be included. Electricity which is used for comfort cooling shall be adjusted upwards by a factor of three for houses which are not electrically heated (Boverket 2008).
} 
Table 1: Requirements for specific energy use and power demand for buildings from 1 January 2010 [6]

\begin{tabular}{|c|c|c|c|c|}
\hline $\begin{array}{l}\text { Climate } \\
\text { zone }\end{array}$ & $\begin{array}{l}\text { Form } \\
\text { heating }\end{array}$ & $\begin{array}{l}\text { Maximal } \\
\text { specific energy } \\
\text { use } \\
{\left[\mathrm{kWh} / \mathrm{m}^{2} \cdot \text { year }\right]}\end{array}$ & $\begin{array}{l}\text { Maximal } \\
\text { installed } \\
\text { electric } \\
\text { power } \\
{[\mathrm{kW}]}\end{array}$ & $\begin{array}{l}\text { Overall heat transfer } \\
\text { coefficient } \\
{\left[\mathrm{W} / \mathrm{m}^{2} \mathrm{~K}\right]}\end{array}$ \\
\hline I & $\begin{array}{l}\text { Electricity, } \\
\text { addition when } \\
A_{\text {temp }}>130 \mathrm{~m}^{2} \\
\text { Other }\end{array}$ & 150 & $\begin{array}{l}6 \\
+0,035\left(A_{\text {temp }}-\right. \\
130) \\
-\end{array}$ & 0,40 \\
\hline II & $\begin{array}{l}\text { Electricity, } \\
\text { addition when } \\
A_{\text {temp }}>130 \mathrm{~m}^{2} \\
\text { Other }\end{array}$ & 75 & $\begin{array}{l}5 \\
+0,030\left(A_{\text {temp }}\right. \\
130) \\
-\end{array}$ & 0,40 \\
\hline III & $\begin{array}{l}\text { Electricity, } \\
\text { addition when } \\
A_{\text {temp }}>130 \mathrm{~m}^{2} \\
\text { Other }\end{array}$ & 55 & $\begin{array}{l}4,5 \\
+0,025\left(A_{\text {temp }}-\right. \\
130) \\
-\end{array}$ & 0,40 \\
\hline
\end{tabular}

\section{The building regulations; problems and opportunities}

When researchers from Dalarna University talked to different housing companies during the summer and autumn of 2007, it was evident that there was concern and speculation on how the building regulations on the improvement of energy efficiency would finally be framed and what this would mean to them. One of the people interviewed said that "there is a proposal, which is being circulated for comments, and which has been postponed a number of times, which says that heat pumps will be classified as electric resistance heating. It has been circulated time and time again and no-one knows when it will be introduced”. But it is clear, the informant said, that the government and the Swedish Board of Housing, Building and Planning want to tighten up the requirements and reduce the use of energy in newbuilt houses (housing manufacturers, group discussion 1).

The housing manufacturers were interviewed during the autumn 2009, which is during the period of transition which started in January 2009. Therefore they had access to the revised wording and the opportunity to digest the changes presented and form a strategy to allow their production to fulfil the requirements for the improvement of energy efficiency. But as 2009 was a period of transition and the regulations did not come into force until 1 January 2010, some housing manufacturers were still ambivalent on how they would deal with the new regulations, and what change would materialise in the end. During 2010, the questions on how they should fulfil the Board of Housing, Building and Planning's requirements have ceased.

\subsection{Insulation thicknesses and tightness}

One change which the interviewees presented was additional insulation in walls and roofs. There are companies which increase insulation from $195 \mathrm{~mm}$ to $240 \mathrm{~mm}$, but there are also companies which keep the thinner insulation and change from air source heat pumps to ground source (rock) heat pumps instead. Most of the interviewees said that a relatively easy measure for improving energy efficiency was thicker walls. One of them said that their manufacturing process was constructed so that further insulation could be added without much trouble and therefore it is not expensive (interview 2) 
One of the interviewees emphasised that more insulation and a thicker wall is less a question of saving energy than of a psychological effect. He said "the saving in energy by constructing a thicker wall is not as great as you think (interview nr 1). He also considered that there was a limit to wall thicknesses as they take up far too much of the floor area if they are too thick. The floor area is limited in prefabricated single-family houses because the transport from the factory to the building owner is by lorry, and they want to limit the number of lorries. A larger house means more lorries, which in turn leads to higher house prices (e.g. in interview 3).

There is a requirement for a limited average heat transfer coefficient in the Swedish Board of Housing, Building and Planning's building regulations (BBR) 2010. This is that the house shall not have a higher average heat transfer coefficient than $0,4 \mathrm{~W} / \mathrm{m}^{2} \mathrm{~K}$ for electrically heated houses and $0,5 \mathrm{~W} / \mathrm{m}^{2} \mathrm{~K}$ if the house has other methods of heating [13]. However, according to Persson and Heier (2010), the requirement for the average heat transfer coefficient is so low that it does not have any practical significance. It is principally the energy and power requirements which set the limits for the insulation standard of the house [14]. There is no specific requirement in BBR on the tightness of the building envelope, only that it shall be sufficiently tight to fulfil the energy and power requirements. The house companies pointed out that if the house purchaser chose to buy the house from them, but selected another company to erect the house, it is the house purchaser, in his role as commissioner of a building project, who is responsible for the building envelope having the required tightness to fulfil the energy requirements. This is an obligation which the interviewees thought could be neglected because the house purchaser was not aware of his/her responsibility (interview nos 7).

\subsection{Choice of heating systems}

There are many different parameters to be considered when choosing a heating system ${ }^{6}$; living area, size of supplementary areas, ventilation, acceptable noise level, economy etc. [9]. The choices open to house manufacturers and house purchasers in Sweden are different types of heat pumps, district heating and bio-fuel boilers or bio-fuel stoves. Solar collectors can be included in all these systems.

In the autumn 2009, the companies were very confident that the air and ground source heat pump manufacturers would improve their products and the products' energy generation, and thereby simplify the work with energy management and the possibility of fulfilling the requirements of the Swedish Board of Housing, Building and Planning (interviews 1, 2, 5 among others). One of the interviewees expected a great change in the production of heat pump products and, according to him, the heat pump suppliers have done "a really good job" (interview 1). During the interviews it was pointed out that one air source heat pump company has become more interesting to the market because of its technology, an improved exhaust air heat pump, and because of the changed building regulations (interviews 6, 4). It is a company which has existed for almost 10 years and has increase its sales from about 30 heat pumps per year to 600 per year (Henning 2009).

The house manufacturers' customers seldom or never choose pellet boilers or pellet stoves Solar heating is also often rejected. The house manufacturers emphasise that bio-fuels are troublesome because they take a lot of space and need a lot of work. They say that the people who are interested in the environment install solar heating (interview 4,5,7). To make the

\footnotetext{
${ }^{6}$ A heating system is not always included in the house sale; if this is not the case the customer can be responsible for the installation him/herself.
} 
disadvantages of pellets and solar heating clear the house manufacturers often emphasise the advantages of air source heat pumps and ground source (rock) heat pumps, for example that they are economical and easy to handle (interviews nr 5,2).

In this study it seems as though the changeover from the traditional exhaust air heat pump, which has the lowest investment cost but the highest total cost, to the improved exhaust air heat pump ${ }^{7}$ took place because the requirements were changed, not because it was, in fact, also financially profitable [15]. The product has existed for a number of years, but the company increased its sales substantially after the revision of BBR in 2010. The new regulations originate in an aim to reduce electrical heating and increase the use of bio-fuels [3, 11] However, Persson and Heier (2010) show that the revised building regulations mean that the choice of a bio-fuel, in this case pellets, needs the supplement of an exhaust and supply air ventilation with heat recovery (hereafter called HRV system). On the other hand ground source (rock) heat pumps fulfil the Swedish Board of Housing, Building and Planning's energy requirements without HRV. Ground source (rock) heat pumps also have an advantage, as the possibility of omitting HRV means a lower investment cost. The interviews show that a low investment cost is an advantage when choosing a heating system for the new house.

\subsection{Current and future changes}

The companies could see opportunities in this energy political goal and in current, as well as in possible future, changes in the building regulations. An example of this is one of the companies which has bought a company which produces low energy houses. They want to take part in, and at the same time follow, a new market with low energy. Therefore, the company has invested in a show house where the building envelope and heating system with heat storage is different from their other standard houses. The show house has extra well insulated walls, solar collectors and district heating and also three storage tanks (total of 750 litres) [16].

However, according to the interviewees, these changes towards more stringent requirements are counteracted by there not being the same requirements for the existing housing stock. There are not the same constraints in spite of the fact that the heating of the existing housing stock requires more energy (interviews nos 2,4,7). One of the interviewees makes the effect of these unequal requirements clear when he says that the stringent requirements for newconstructed dwellings can lead to too high prices for some of the prospective house owners. They choose to buy an older house instead (interview 1).

The interviewed manufacturers that produce vacation homes sold within the region of Dalarna, also have to adjust to the requirements specified for permanent homes. This is because even thought the vacation homes are not affected by the energy requirements in the government building regulations, Malung -Sälen municipality has started to insist the vacation homes follow the same requirements as permanent homes. This is because new buildings in Malung - Sälen municipality is manly of vacation houses which have similar designs to permanent houses and therefore similar energy demands. If these do not follow the more stringent energy regulations, the energy demand will increase and may require an increase in the capacity of the power distribution net. (interview 4,5 and a politician from Malung-Sälen).

\footnotetext{
${ }^{7}$ An improved exhaust air heat pump is an electrically driven heat pump which cools the exhaust air to approximately $-15^{\circ} \mathrm{C}$, and also makes use of heat from condensation of the humidity in the air.
} 


\section{Conclusions}

If we use Evert Vedung's concepts and model, this study shows that the immediate outcome of the Swedish Board of Housing, Building and Planning's building regulations from 2010 regarding the improvement of energy efficiency is, in some cases, an improvement of the building envelope, in particular supplementary insulation of the walls, but above all a changeover from an exhaust air heat pump to either an improved exhaust air heat pump or a ground source (rock) heat pump.

The intermediate outcome is that prospective house owners choose to buy an older house with a high energy consumption instead of a new with less energy demand. The changes towards more stringent requirements are counteracted by there not being the same requirements for the existing housing stock. Prospective house owners choose to buy an older house instead of a new one, because of higher prices caused of the stringent requirements for new constructed dwellings. To make it attractive for a prospective house owner to build a house it is also important to focus on regulations concerning the existing building stock and energy use.

The intermediate outcome is also a question of increased performance of exhaust air heat pumps and the effects of this. Increasing insulation was not always a result of the Swedish Board of Housing, Building and Planning's energy requirements. The requirements could be fulfilled with the help of a more efficient air source heat pump instead. A parallel can be drawn between this study and a Norwegian study on state intervention and house manufacture. The Norwegian study shows that state regulations are regarded as an indication of the least which should be done and the smallest possible changes are carried out [17]. It is interesting, though, that in contrast to the manufacturers, Malung-Sälen municipality requests more than what is defined in the building regulations. The vacation houses are being used mainly during the winter and are the same size as permanent houses ${ }^{8}$ the interviewed emphasized the importance of having the same requirements for all the new built houses. That is to prevent for instance the need to expand the power distribution grid.

The final outcome of this study is that the new building regulations do not automatically lead to better insulated houses. The conclusion is that it is sufficient to change from an ordinary exhaust air heat pump to an improved exhaust air heat pump or a ground source heat pump. A trend, where heat pumps and (electrically heated) passive houses continue to dominate Swedish house production means that the housing stock is becoming more and more based on electric heating. It is true that the houses fulfil the requirements in the building regulations, but, at the same time, they increase the problem of high power loads during the winter which demand great flexibility in production capacity.

The building regulations focus on reducing the households' bought energy instead of climate impact. From a regional and vacation houses perspective this is interesting, because the log house industry feels that its work and normally bio-fuel heated houses are threatened. From a climate perspective it can be discussed if a log house built and heated with wood from the region is not preferable to a low energy house built in concrete and heated with a ground source heat pump [see also 18].

\footnotetext{
${ }^{8}$ For example, the average size of the houses produced by one of the manufacturers was $120 \mathrm{~m}^{2}$ (interview 6)
} 


\section{Acknowledgements}

This work was financed within the project SWX-Energi, financed by the European Union, Region Dalarna, Region Gävleborg and Högskolan Dalarna.

\section{References}

[1] Proposition 2004/05:150, Svenska miljömål: ett gemensamt uppdrag.

[2] Proposition 2008/09:163, Energi. En sammanhållen klimat- och energipolitik.

[3] SOU 2008:110, Energieffektiviseringsutredningen. Vägen till ett energieffektivare Sverige.

[4] SCB, Energistatistik för småhus 2008.

[5] EU, Färdplan för förnybar energi. Meddelande från kommissionen till rådet och EUparlamentet, 2008.

[6] Boverket, Regelsamling för byggande, BBR 2008: supplement februari 2009, 9 Energihushållning, 2009.

[7] Vedung, E., Utvärdering i politik och förvaltning. Studentlitteratur: Lund, 1 ed., 2002.

[8] Perman, K., Byggregler och småhustillverkare i Dalarna, in Klimatsmart villavärme? Solvärm, nya byggregler och möjligheten att förändra, Henning A. (ed), Falun: Centrum för solenergicentrum (SERC), Högskolan Dalarna, 2010.

[9] Henning, A., Vem fattar beslut om värmesystemen i monteringsfärdiga småhus?, in Klimatsmart villavärme? Solvärme, nya byggregler och möjligheten att förändra, Henning A. (ed). Falun: Centrum för solenergicentrum (SERC), Högskolan Dalarna. 2010.

10] Perman, K, Från el till värme : en diskursanalytisk policystudie av energiomställning på statlig, kommunal och hushållsnivå. Örebro: Örebro universitet. Örebro Studies in Political Science 23, 2008.

[11] Proposition 2005/06:145, Nationellt program för energieffektivisering och energismart byggande.

[12] SFS 2008:51, Förordning om ändring i förordningen (1994:1215) om tekniska egenskapskrav på byggnadsverk, m.m.

[13] Boverket, Regelsamling för byggande, BBR 2008; supplement februari 2009, 9 Energihushållning, 2009.

[14] Persson, T. and J. Heier, Småhusens framtida utformning - Hur påverkar Boverkets nya byggregler? Falun: Centrum för solenergiforskning (SERC), Högskolan Dalarna, 2010.

[15] Henning, A. (ed), Klimatsmart villavärme? Solvärme, nya byggregler och möjligheter, Falun: Centrum för solenergiforskning (SERC), Högskolan Dalarna, 2010.

[16] Lorentz, K., Möten med husföretag, in Klimatsmart villavärme? Solvärme, nya byggregler och möjligheten att förändra, Henning A. (ed), Falun: Centrum för solenergiforskning, Högskolan Dalarna, 2010.

[17] Ryghaug, M. and K.H. Sørensen, How energy efficiency fails in the building industry. Energy Policy 37, 2009, p. 984-991.

[18] Janols, H., F. Lindberg, and I. Nygren, Uppgradering av traditionellt byggsystem. Delprojekt 1: Produktutveckling- timmerhus och energihushållning, Falun: Akademin Industri och samhälle, Högskolan Dalarna, 2010. 